\title{
ICT and the UN's Sustainable Development Goal for Education: Using ICT to Boost the Math Performance of Immigrant Youths in the US
}

\author{
Sunha Kim \\ Department of Counseling, School, and Educational Psychology, SUNY at Buffalo, 423 Baldy Hall, Buffalo, \\ NY 14260, USA; sunhakim@buffalo.edu; Tel.: +1-716-645-1127
}

Received: 30 October 2018; Accepted: 18 November 2018; Published: 4 December 2018

\begin{abstract}
In the context of the United Nations' Sustainable Development Goal for education, this study examines the potential of information, communication, and technology (ICT) as a way to provide quality education for all, with a focus on immigrant youth in the United States. The study uses structural equation models (SEM) to analyze data from a nationally representative data set, Trends in International Mathematics and Science Study (TIMSS)-USA. Focusing on mathematics achievement among immigrant youth (with non-immigrant youth as a reference group), this study explores the effects of ICT access and two types of ICT use for educational purposes: generic and specific. The results indicate that ICT access and specific ICT use both have positive direct, indirect, and total effects on math performance for immigrant youths, while generic ICT use has only a nonsignificant negative effect. In nonimmigrant youths, these ICT variables showed a different pattern, with the effects of ICT access and specific ICT use being less pronounced, but generic ICT use exhibiting a significant negative effect. These findings show the potential role of ICT-mediated education in narrowing the achievement gap between immigrant and nonimmigrant students, thereby helping immigrants better integrate into their destination countries.
\end{abstract}

Keywords: ICT; immigrant students; sustainable development goal

\section{Introduction}

Globally, the number of international migrants has increased dramatically in recent years, rising from 173 million in 2000 to 258 million in 2017; this increase in international migration has accounted for approximately 40 percent of the population increase in North America over the past 10 years [1]. International migration is not expected to decline from the current levels anytime soon [2] and it is estimated that by 2050 there could be as many as 405 million international migrants [3]. In our increasingly interconnected world, international migration is a critical factor in sustainable development [4], and it is crucial that efforts should be made to help migrants integrate into their destination nations [5]. The United Nations' (UN) Sustainable Development Goal for education promotes the provision of quality education for all as an important way to facilitate the integration of migrants [1]. In pursuit of the UN's Sustainable Development Goal for education, this study therefore examined the impact of providing quality education via information, communication, and technology (ICT) for recent immigrants who have settled in the United States), which is home to more international migrants than any other country (50 million) [1].

This study focuses on immigrant youths who are not free from immigrant risks and who are suffering from lower academic achievement than their nonimmigrant peers and students in high-poverty, K-12 schools throughout the U.S. [6,7]. The study explores ICT's potential to promote the performance of immigrant youth in mathematics, which fosters 21 st century skills, such as problem 
solving and critical thinking [8,9]. Specifically, this study explores the potential of ICT to promote quality education by providing extensive access to educational resources for immigrant youth, who often lack educational resources at home or in their communities, in accordance with international and U.S. initiatives to provide equal access to ICT resources [5] and the Digital Equity Act of 2015 [10]. In addition to ICT access, given the mixed results on ICT use, in order to develop a set of clear guidelines for educators, this study investigates two types of ICT, namely specific and generic ICT. When used for specific educational purposes, ICT can promote meaningful learning in the context of formal learning and improve immigrant students' mathematics performance. Conversely, generic ICT use without a specific educational purpose can have an adverse influence [11,12].

This study is guided by the following objectives:

- Examine whether immigrant students exhibit lower mathematics performance than their nonimmigrant peers;

- Investigate whether/how ICT access promotes mathematics performance for immigrant students;

- Examine whether/how different types of ICT use enhance/constrain learning for immigrant students;

- Identify whether the association between ICT access/use and mathematic performance differs across immigrant status, thus exploring ICT as a potential way to narrow the achievement gap between immigrant and nonimmigrant students.

The study adopts a comprehensive approach by exploring the effects of ICT on not only mathematical performance but also self-efficacy, which plays a critical role in mathematics achievement [13] but is lower among immigrant students than their non-immigrant peers [14]. Using nationally representative data from the Trends in International Mathematics and Science Study (TIMSS)-USA, a series of full structural equation models (Full SEM) that include math self-efficacy as a mediator are conducted, controlling for student gender, parents' educational level, and home resources $[15,16]$.

\section{Literature Review}

\subsection{ICT Use among Youth}

Educators and policy-makers have high expectations that ICT will produce helpful innovations in teaching and learning practices, although they also have some concerns about the potential negative effects of ICT use on students, including poorer physical health, increased vulnerability to cyberbullying, suicide, and binge drinking [17-20]. For educators seeking to prepare their students for tomorrow's knowledge society, ICT is a critical resource. It is also thought to promote deep learning among present-day students, who have adopted and engaged in ICT at unprecedented levels [21]. Students in today's digitally rich environment have been diversely labeled as "the net generation" [22], "digital natives" [23], "digital learners" [24], "the iKid generation" [25], and "the wired generation" [26]. ICT competency is essential for these students, if they are to develop the skills needed to thrive in the era of the knowledge society, in which employees must adapt to rapid global innovations in ICT in order to engage in continuous learning and solve increasingly complex tasks [27].

\subsection{ICT and Immigrants}

To further examine the expectation that ICT can expand opportunities for disadvantaged students and thus improve their academic performance [28], this study focuses on immigrant students in U.S. public schools, a population currently estimated at around 4.6 million [29]. According to the U.S. Department of Education's national report [30], as long as national assessments have been conducted, immigrant students have had lower academic performance than their non-immigrant peers, even in subjects such as mathematics that would appear to require less linguistic ability. Further, this achievement gap is larger in the higher grades. While there is some initial evidence of ICT's potential 
to improve academic achievement among immigrant youth [31], more studies are required to identify policy-relevant findings based on empirical investigations of the effect of ICT-mediated education on immigrant youth.

\subsection{ICT Access}

Access to ICT is important because it provides a way to obtain educational/practical information as well as enabling users to engage in a variety of social interactions, including collaboration and communication, that are not limited by either geography or time [32]. Existing studies on the potential benefits of ICT access have focused on computers and the Internet. Researchers have found significant positive relationships between computer access and academic achievement in many subjects, including reading, mathematics, and science [33,34]. Similarly, Internet access has been found to be a significant predictor of students' academic success [35]. These positive relationships may emerge, in part, because high-SES parents are not only more likely to provide access to multiple ICTs in the home as educational resources for their children, but are also more likely to confer other educational and economic benefits on their children [36].

Worldwide, there are approximately 2.9 billion internet users, the majority of whom are school-aged young people, and students' access to computers and the internet at home and at school has increased greatly in recent years [37]. Moreover, citing the importance of recent digital innovations, the 2017 OECD Digital Economy Outlook [5] stressed the need for more investment funding to expand access to recently developed ICTs, beyond computers and the internet. Thus, while the extant findings on the positive relationship between academic achievement and students' access to ICT such as computers and the Internet [38] are valuable, more studies are needed to explore the effects of access to ICT resources, especially the most recent innovations.

In response, the current study examines the effects of access to existing/new ICT resources among immigrant students and explores whether access to these ICT resources has a positive influence on students' performance.

\subsection{Types of ICT Use: Generic and Specific}

Although researchers have made great efforts to investigate the relationship between ICT use and academic achievement, the results have been mixed, with some prior studies finding a positive effect e.g., [33], while others find no effect or even a negative effect, e.g., [39]. To attempt to make sense of these results, some researchers have focused on whether the setting influences the relationship between ICT use and academic achievement. Their findings suggest that home ICT use is associated with higher academic performance, but more frequent ICT use at school is associated with lower academic achievement [40-42]. This difference in the results across settings might be explained by the specific purposes for which the students use ICT. The negative relationship between school-based ICT use and academic achievement might be due to the fact that low-performing students are being asked to use ICT at school more frequently in order to boost their performance, thus tending to spend most of this time using ICT to improve their low performance instead of engaging in more enriching class activities [43].

In addition to this focus on exploring the effects of different settings, there has been a call for researchers to investigate the specific purposes of ICT, which could also be moderating the impact of ICT use on student achievement [44]. Studies have found that while ICT use for general educational purposes is negatively associated with academic performance, ICT use for specific purposes is positively associated with academic performance $[45,46]$. Some researchers have therefore recommended that ICT should be used in the context of the curriculum, for example, to complete homework assignments [47-49]. Using ICT for generic educational purposes that are not directly related to the curriculum has a negative impact on students' academic performance, but ICT use for assignments can produce improvements in academic performance given the well-researched connections between assignments in traditional settings and educational attainment $[45,46,50]$. Other 
studies have identified the benefits of ICT use for purposes such as collaboration and communication in the framework suggested by Jonassen [11,51], who recommends using ICT as a set of cognitive tools to aid students' constructivist activities such as problem-solving. For example, using ICT for collaboration has the potential to promote deeper learning via social interaction and negotiation skills, both of which are positively related to problem-solving [52,53]. In addition, in line with the general concept of problem-solving as a constructive activity [54], students are frequently asked to apply problem-solving skills to complete tasks such as ICT-based communication. Researchers have found that students' communication patterns when using ICT are very similar to communication during problem-solving activities; both include problem definition and solution creation, for example [55].

As part of our search for a type of ICT use that will promote academic achievement among immigrant students, in this study we moved beyond these prior studies' exploration of how settings influence the impact of ICT use by differentiating between ICT use for general schoolwork and ICT use for specific educational purposes.

\subsection{Self-Efficacy}

Referring to an individual's perception of his or her own competency in achieving goals [56], self-efficacy has long been deemed a critical determinant of academic success [57-59]. ICT researchers have examined the potential of ICT use on improving self-efficacy, emphasizing the importance of identifying specific types of ICT uses for self-efficacy [60]. Several studies have examined whether self-efficacy mediates the relationship between ICT use and academic achievement. For example, $\mathrm{Zhu}$, Chen, Chen, and Chern [61] found that ICT use for a specific purpose such as information seeking positively influenced students' self-efficacy, which in turn improved the students' academic achievement. Similarly, Chen, Hsiao, Chern, and Chen [62] found self-efficacy mediated the effect of ICT use for specific educational purposes on academic performance, with these effects also being influenced by the students' characteristics. Corresponding to potential differences in the effects of ICT across different student characteristics, some studies have paid particular attention to status, revealing different patterns in the relationships between ICT use, self-efficacy, and academic achievement depending on the students' immigration status [14].

\subsection{Gender}

Studies on gender differences in academic performance have shown mixed results. While some studies employing meta-analyses or nationally representative data have found gender similarities [63-66]; other studies using similar approaches have detected gender differences $[31,67,68]$. A similar pattern was identified for self-efficacy. Some scholars have reported that boys revealed higher self-efficacy [69], but others found no evidence to support self-efficacy differences across genders [60]. In the case of ICT, although no gender differences have been reported related to obtaining learning gains from ICT-mediated learning $[70,71]$, there have been gender differences identified in the preferences for activities. While female students were more likely to use ICT for educational purposes [72], male students tended to spend more time on noneducational ICT activities, such as digital games $[73,74]$.

\section{Materials and Methods}

\subsection{Data and Variables}

The Trends in International Mathematics and Science Study (TIMSS), which is sponsored by the International Association for the Evaluation of Educational Achievement, assesses the mathematics and science performance of fourth- and eighth-grade students in OECD countries [15]. The current study uses eighth graders' mathematics assessment data from the TIMSS 2015 International U.S. database, which was managed by the National Center for Education Statistics (NCES) in the U.S. Participants were nationally representative samples of U.S. eighth graders who were selected using a two-stage 
stratified cluster sampling design. In the first stage, the participating schools were sampled from among all the public and private schools in the U.S. using a systematic probability-proportional-to-size (PPS) technique, and during the second stage, mathematics classes were randomly selected and all students in the selected classes were chosen for the TIMSS assessments. The weighted number of sampled students for TIMSS in the USA were 3,627,353 eighth graders, of whom 1,814,932 were male and 1,812,421 female.

The primary endogenous variable in the study is math performance, measured by five plausible values (math). Plausible values allowed the estimation of a probability distribution of each student's ability, which is beneficial in test conditions where there are too few items to assess students' ability accurately. A second endogenous variable is mathematics self-efficacy (efficacy), which was measured by four items (effi1, effi2, effi3, and effi4) by asking students about their degree of agreement with the following statements: "[I] Usually do well in math; [I] learn quickly in mathematics; [I am] good at working out math problems; and I am good at mathematics." Responses ranged from 1 (agree a lot) to 4 (disagree a lot). These self-efficacy variables were reverse-coded for clearer interpretation.

The predictors of chief interest are three ICT variables: ICT access, generic ICT use, and specific ICT use. Students' access to ICT resources (ICT access) is measured by the number of digital information devices in a student's homes. Students reported the number of devices in their homes, including computers, tablets, smartphones, smart TVs, and e-readers. ICT use for general schoolwork (generic ICT) was measured by three items (generic1, generic 2, and generic 3 ), which asked respondents how frequently they used a computer or a tablet for schoolwork at home, at school, and in other places, with answers ranging from 1 (every day or almost every day) to 4 (never or almost never). The variables related to ICT use for specific purposes (specific ICT) assessed whether students used the Internet to access assignments posted online by their teachers, to collaborate with classmates on assignments or projects, and to communicate with teachers; each item was coded 1 for yes and 0 for no. The three ICT use variables (specific1, specific 2, and specific 3) were reverse-coded for clear interpretation.

To examine the effects of these ICT variables, the study compared the main group of interest, immigrant students (immigrant), to a reference group of non-immigrant students (non-immigrant). TIMSS asked students, "Were you born in the US?", "Was your mother (or stepmother or female guardian) born in the US?", "Was your father (or stepfather or male guardian) born in the US?", and "How often do you speak English at home?". The current study uses these variables to identify immigrant students: foreign-born students (first-generation); and students with at least one foreign-born parent who often speak languages other than English at home (second-generation) [75]. As this study focused on immigrant students who are exposed to immigrant risks, this study included both first- and second- generation immigrant students. While second-generation students are generally known to gain some immigrant advantages, second-generation students whose primary language at home is not English are as vulnerable to immigrant risks such as low academic achievement as first-generation students [76,77]. In addition, the study included three control variables: gender (gender: 1 = female; 0 = male); parents' highest education level (parents), ranging from 1 (some primary, lower secondary, or no school) to 5 (university or higher); and home education resources (resources), a TIMSS scale with a higher value representing more resources.

\subsection{Analysis}

The study conducted preliminary analyses, including t-tests, using the IEA International Database (IDB) Analyzer software, which employs sampling weights and jackknife repeated replication to account for the complex sampling procedure of TIMSS [17]. Further, reliability tests were conducted to explore the internal consistency of items for the constructs of self-efficacy, generic ICT, and specific ICT. Exploratory factor analysis (EFA) was performed to explore the factorial structure of the ICT use construct, with one factor being for ICT use, while two separate factors were utilized to represent generic ICT and specific ICT. Using Mplus 8.1 with the oblique rotation of GEOMIN as the default rotation method [78], EFA was conducted in the context of Exploratory SEM (ESEM), integrating EFA 
and confirmatory factor analysis (CFA) to take advantage of both the free estimation of factor loadings in EFA and the fit statistics provided by CFA [79]. As a part of ESEM, a scree plot was developed as a convenient way to represent the number of factors (constructs) visually. After the EFA was completed, CFA was carried out to estimate the relationship between the latent variables (factors) and the observed variables (the respective items) through the various factor loadings.

The main statistical analysis consisted of a series of full SEM models, by integrating a CFA (measurement model) and a structural model using Mplus 8.1 [78]. The structural model used structure coefficients (direct, indirect, and total effects) to explore the relationship between the latent variables from the measurement model and other study variables. The study included gender, parents' education, and home education resources as covariates in the structural model and investigated the extent to which the ICT variables of interest (e.g., ICT access, generic ICT use, and specific ICT use) predicted math achievement via direct paths (direct effects). The structural model also included math self-efficacy as a mediator, to assess the indirect effects of the three ICT variables on math achievement via self-efficacy. Finally, the total effects were estimated by combining both the direct and indirect paths. Figure 1 is a graphic representation of the relationships between the variables in the full SEM model.

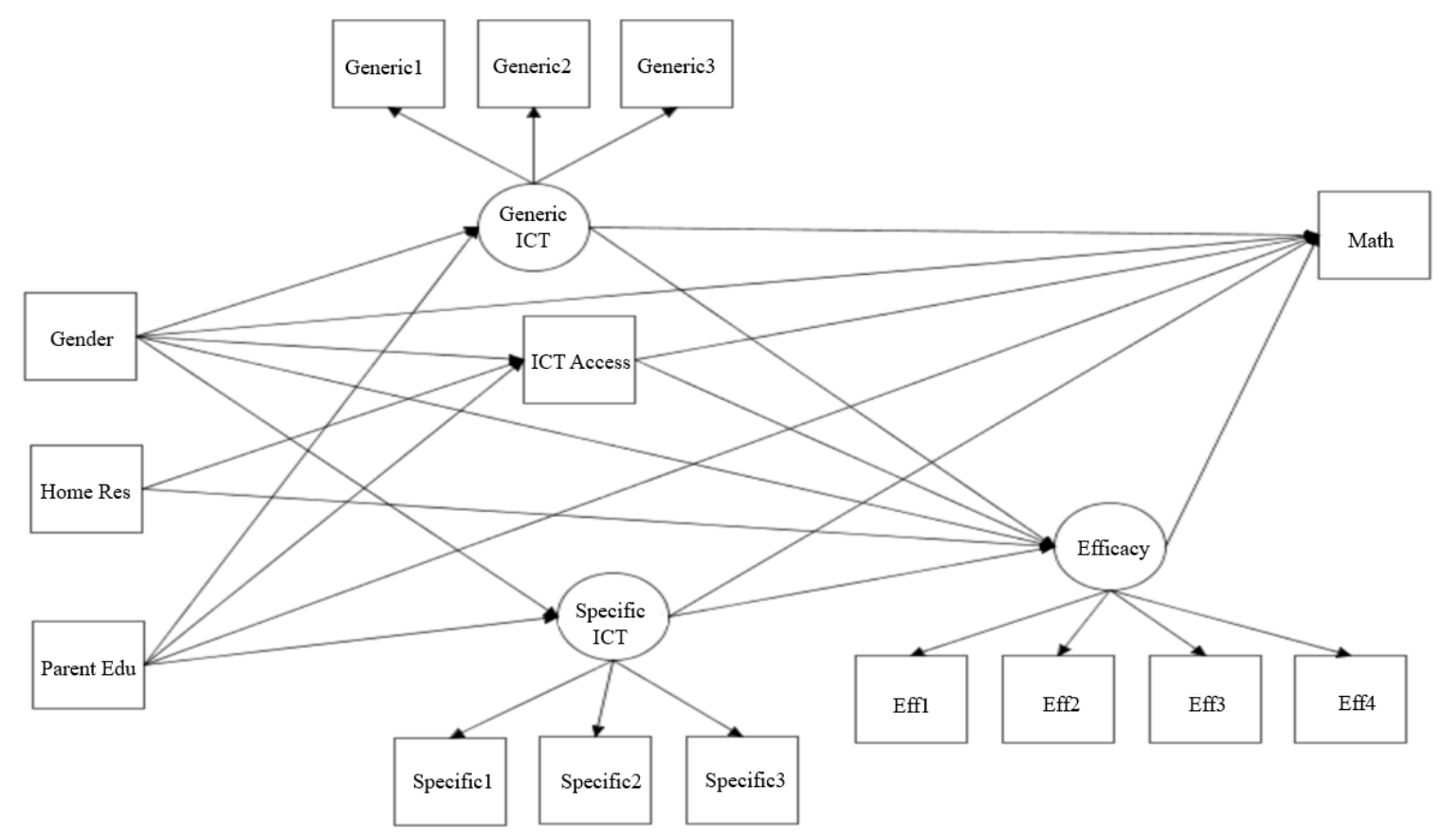

Figure 1. Hypothesized model.

This study utilized two SEM models, one for immigrant students and one for non-immigrant students. Considering the possible non-normality issues, this study adopted the robust maximum likelihood estimator (MLR), which is known for its robustness and ability to cope with violations of normality in the data $[78,80]$. Five fit indices were used to evaluate the overall model fit $[78,81,82]$ : chi-square $\left(X^{2}\right)$, the root-mean square error of approximation (RMSEA), the comparative fit index (CFI), the Tucker Lewis Index (TLI), and the standardized root mean square residual (SRMR). Though insignificant results for the chi-square statistics revealed a good fit, significant results with a sample size greater than 200 are also acceptable with other fit indexes that show good fits [83]. The following a priori criteria were set for acceptable fit for the following indices [84-86]: RMSEA values less than 0.08, CFI and TLI values greater than 0.90 , and SRMR values less than 0.08 . 


\section{Results}

\subsection{Preliminary Data Analysis}

As shown in Table 1, immigrant students comprised $10.29 \%$ (weighted $N=373,179$ ) of the total student population (weighted $N=3,627,655$ ), while non-immigrant students comprised $89.71 \%$ (weighted $N=3,254,655$ ) of all students. The correlation results show that all variables were significantly associated with math achievement. With respect to the ICT variables, all ICT access and use variables were positively correlated with mathematics achievement. In addition, all ICT variables, had significant positive correlations with self-efficacy, except non-significant correlation between ICT access and Effi4, showing that, on average, students with greater ICT access or use reported a higher degree of math self-efficacy.

The $t$-test results showed significantly lower mathematics performance among immigrant students $($ mean $=512.91)$ than nonimmigrant students $($ mean $=519.08)$ with a $t$-value of $1.99(p<0.05)$, as shown in Table 1. Results also revealed a lower level of ICT access among immigrants than among their peers $(t=5.98, p<0.01)$. Similarly, compared with their nonimmigrant peers, parents of immigrant students had lower educational levels $(t=13.39, p<0.01)$ and immigrant students come from families with fewer home resources $(t=14.91, p<0.01)$.

To explore the internal consistency among items for the constructs, this study obtained reliabilities for specific ICT, generic ICT, and self-efficacy. The reliability of self-efficacy was good with 0.897 but, reliabilities of specific ICT and generic ICT were lower with 0.527 and 0.615 , respectively. To further explore the factor structure for ICT variables (one ICT construct vs. two separate constructs), ESEM were performed. A two-factor ESEM model showed better factor structure and model fits compared with a one-factor ESEM model, thus supporting two separate constructs of specific and generic ICT. As shown in a spree plot (Figure 2), two factors emerged with its eigenvalue greater than one, instead of one factor. While a one-factor ESEM model did not have acceptable fit statistics with RMSEA $>0.08$, and CFI and TLI $<0.90$, a two-factor ESEM model showed acceptable fit statistics with RMSEA $<0.08$, and CFI and TLI > 0.90 (Table 2).

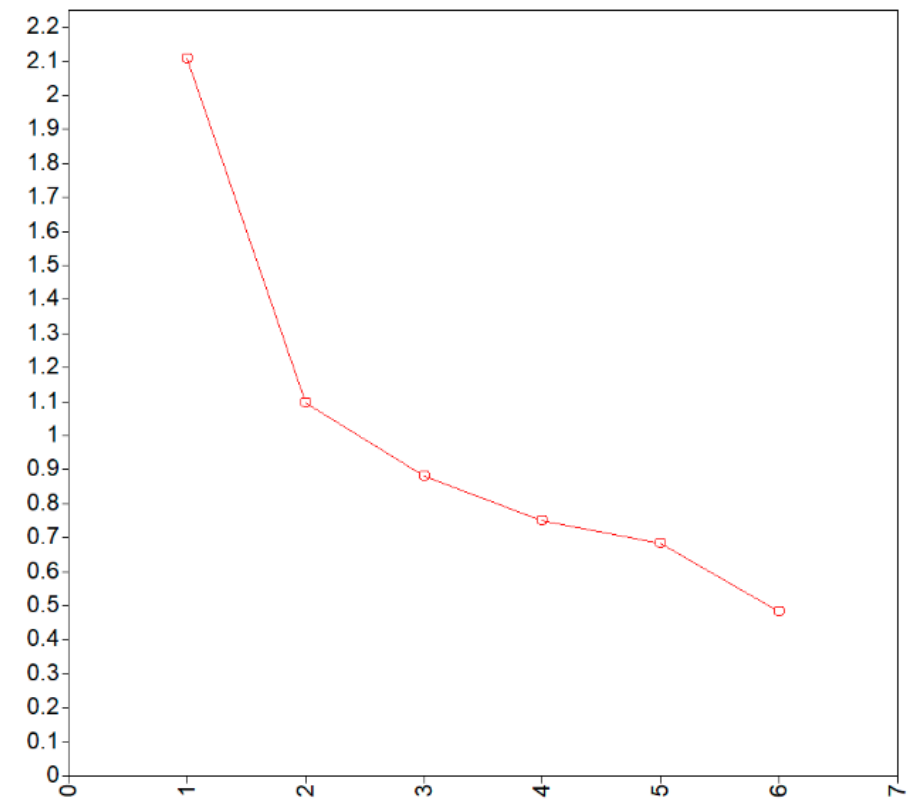

Figure 2. Spree plot. 
Table 1. Descriptive Statistics, Correlation and $t$-Test Results.

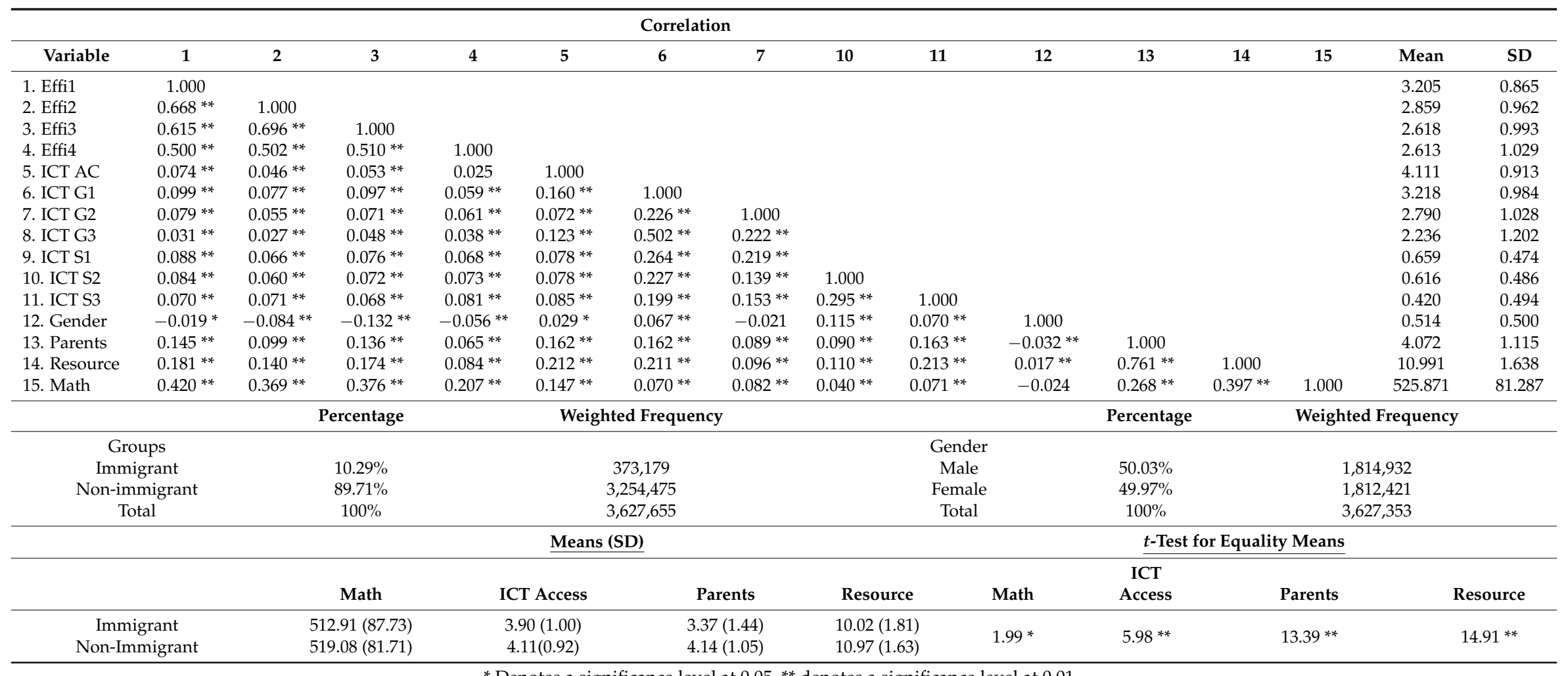

${ }^{*}$ Denotes a significance level at $0.05,{ }^{* *}$ denotes a significance level at 0.01 . 
Table 2. Exploratory SEM (ESEM) Model Fit Statistics.

\begin{tabular}{cccccc}
\hline & Chi-Square & RMSEA & CFI & TLI & SRMR \\
\hline One-Factor ESEM & $1363.442, p<0.05$ & 0.122 & 0.803 & 0.671 & 0.061 \\
Two-Factor ESEM & $119.651, p<0.05$ & 0.053 & 0.983 & 0.937 & 0.016 \\
\hline
\end{tabular}

As shown in the below Table 3, a two-factor CFA model for ICT (ICT CFA) and a one-factor CFA model for self-efficacy (Efficacy CFA) showed good factor loadings and acceptable fit statistics. In the ICT CFA model, the relationship between the latent factor and respective variables were significant with factor loadings ranging from 0.415 and to 0.682 , greater than the cut-off value of 0.3 [87]. In the Efficacy CFA model, the relationship between the latent factor and respective variables were significant with factor loadings greater than 0.60 .

Table 3. Confirmatory Factor Analysis (CFA) Results.

\begin{tabular}{cccccc}
\hline & Chi-Square & RMSEA & CFI & TLI & SRMR \\
\hline ICT CFA & $165.891, p<0.05$ & 0.051 & 0.977 & 0.942 & 0.020 \\
Efficacy CFA & $96.021, p<0.05$ & 0.068 & 0.995 & 0.984 & 0.011 \\
\hline Generic ICT & Factor Loading $(\lambda)$ & Specific ICT & Factor Loading $(\lambda)$ & Self-Efficacy & Factor Loading $(\lambda)$ \\
\hline Generic 1 & $0.515^{* *}$ & Specific 1 & $0.531^{* *}$ & Effi1 & $0.782^{* *}$ \\
Generic 2 & $0.415^{* *}$ & Specific 2 & $0.483^{* *}$ & Effi2 & $0.852^{* *}$ \\
Generic 2 & $0.682^{* *}$ & Specific 2 & $0.527^{* *}$ & Effi3 & $0.812^{* *}$ \\
& & & & Effi4 & $0.614^{* *}$ \\
\hline
\end{tabular}

** Denotes a significance level at 0.01 .

\subsection{Full SEM Model for Immigrant Students (Immigrant Model)}

Table 4 indicates that the full SEM model for immigrant students revealed acceptable fit statistics: $X^{2}=216.470, p<0.05 ; \mathrm{RMSEA}=0.045<0.08 ; \mathrm{CFI}=0.944>0.90 ; \mathrm{TLI}=0.915>0.90 ; \mathrm{SRMR}=0.038<0.08$.

Table 4. Model Fit Statistics.

\begin{tabular}{cccccc}
\hline & Chi-Square & RMSEA & CFI & TLI & SRMR \\
\hline Immigrant & $216.470, p<0.05$ & 0.045 & 0.944 & 0.915 & 0.038 \\
Non-immigrant & $1276.541, p<0.05$ & 0.045 & 0.946 & 0.915 & 0.041 \\
\hline
\end{tabular}

Figure 3 shows the parameter estimates from both the measurement and the structural models. With the factor loading of ICT Generic1 fixed to 1, the factor loadings of the two other ICT Generic variables, ICT Generic $2(\lambda=0.453, p<0.01)$ and ICT Generic $3(\lambda=1.010, p<0.01)$, were significant. With the factor loading of ICT Specific1 set to 1 , two observed variables, ICT Specific2 $(\lambda=0.604$, $p<0.01)$ and ICT Specific3 $(\lambda=0.875, p<0.01)$, were significant. With the factor loading of Eff1 set to 1 , three observed variables, Eff2 $(\lambda=1.153, p<0.01), \operatorname{Eff} 3(\lambda=1.089, p<0.01)$, and Eff4 $(\lambda=0.936$, $p<0.01$, were significant. The factor loading results showed that the observed variables loaded onto their respective factors as shown by the measurement model. 


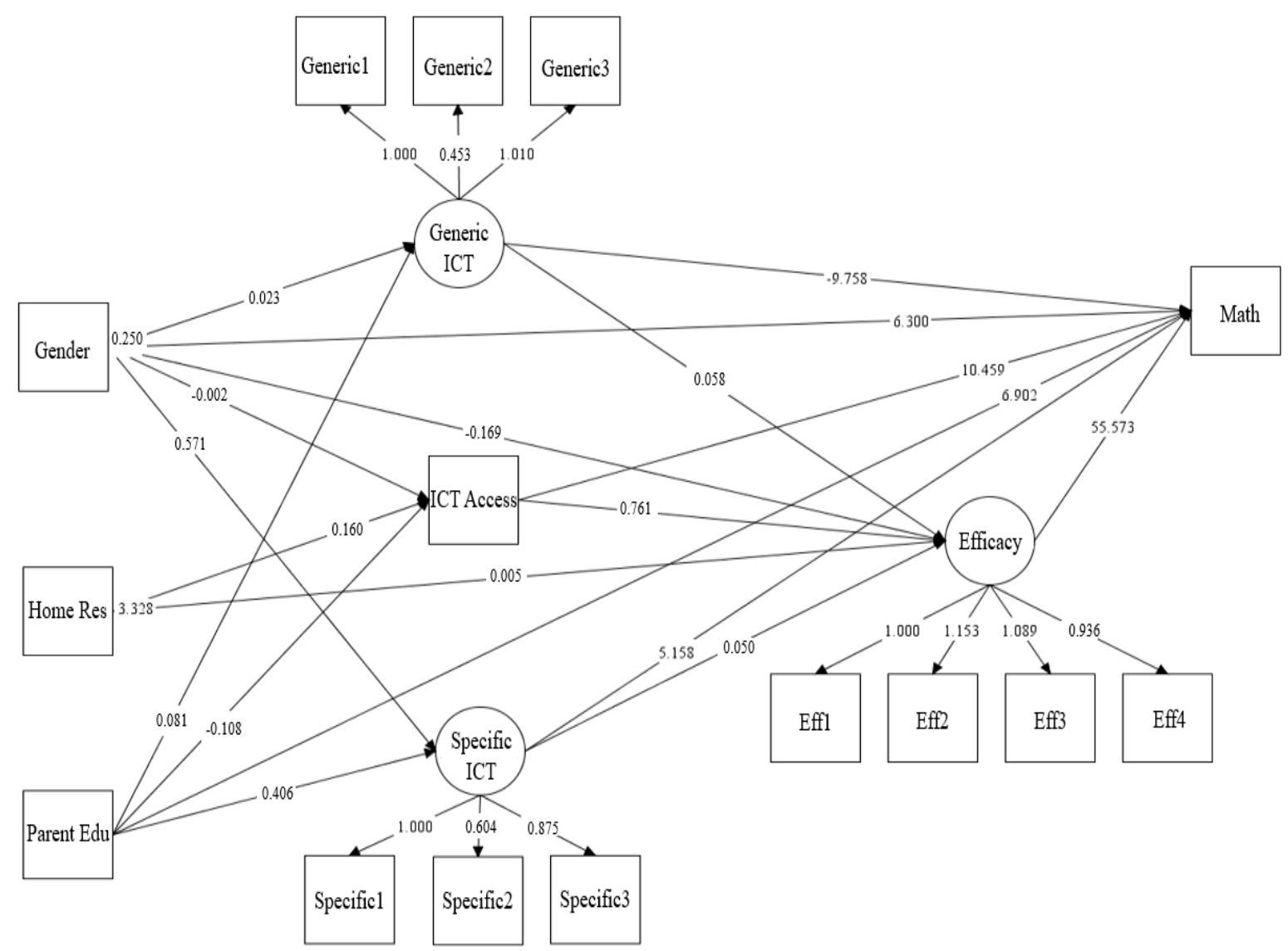

Figure 3. Full SEM Results for Immigrant Model.

Figure 3 displays the direct effects in the structural model while Table 5 presents indirect and total effects. ICT access had significant positive direct and total effects on math $\left(\beta_{\text {direct }}=10.431, p<0.01\right.$; $\left.\beta_{\text {total }}=52.769, p<0.05\right)$, but, did not have significant association with math self-efficacy. Among immigrant students, those with more ICT access had higher levels of mathematics.

Table 5. Direct, Indirect and Total Effects of Models.

\begin{tabular}{|c|c|c|c|c|c|c|}
\hline \multirow{2}{*}{ Effect } & \multicolumn{2}{|c|}{ Direct Effect } & \multicolumn{2}{|c|}{ Indirect Effect } & \multicolumn{2}{|c|}{ Total Effect } \\
\hline & Immigrant & Nonimmigrant & Immigrant & Nonimmigrant & Immigrant & Nonimmigrant \\
\hline ICT Access $\rightarrow$ Math & $10.431^{* *}$ & $8.890^{* *}$ & 42.31 & -51.978 & $52.769 *$ & -43.088 \\
\hline ICT Access $\rightarrow$ Self-Efficacy & 0.761 & -1.042 & & & 0.761 & -1.042 \\
\hline Generic ICT Use $\rightarrow$ Math & -9.758 & $-10.574^{* *}$ & 3.198 & $2.400 * *$ & -6.56 & $-8.174^{* *}$ \\
\hline $\begin{array}{l}\text { Generic ICT Use } \rightarrow \\
\quad \text { Self-Efficacy }\end{array}$ & 0.058 & $0.048^{* *}$ & & & $0.06 * *$ & $0.048^{* *}$ \\
\hline Specific ICT Use $\rightarrow$ Math & $5.158 *$ & 1.751 & $2.753 *$ & $3.101 * *$ & 7.910 ** & $4.852 * *$ \\
\hline $\begin{array}{l}\text { Specific ICT Use } \rightarrow \\
\quad \text { Self-Efficacy }\end{array}$ & $0.050 *$ & $0.062 * *$ & & & $0.050 *$ & $0.062 * *$ \\
\hline Self-Efficacy $\rightarrow$ Math & $55.573 * *$ & $49.901 * *$ & & & $55.573^{* *}$ & $49.901 * *$ \\
\hline Gender $\rightarrow$ Math & 6.3 & 2.064 & -5.152 & $-4.485^{* *}$ & 1.148 & -2.421 \\
\hline Gender $\rightarrow$ Self-Efficacy & $-0.169 *$ & -0.063 & 0.028 & -0.029 & $-0.141^{* *}$ & $-0.093^{* *}$ \\
\hline Gender $\rightarrow$ ICT Access & -0.002 & $0.053 *$ & & & -0.002 & $0.053 *$ \\
\hline Gender $\rightarrow$ Generic ICT Use & 0.023 & $0.089 * *$ & & & 0.023 & $0.089 * *$ \\
\hline Gender $\rightarrow$ Specific ICT Use & $0.571 * *$ & $0.344^{* *}$ & & & $0.571 * *$ & $0.344^{* *}$ \\
\hline Parent Education $\rightarrow$ Math & $6.902 * *$ & $15.701^{* *}$ & -3.011 & -0.443 & 3.891 & $15.258^{* *}$ \\
\hline $\begin{array}{c}\text { Parent Education } \rightarrow \text { ICT } \\
\text { Access }\end{array}$ & -0.108 * & 0.019 & & & $-0.108 *$ & 0.019 \\
\hline
\end{tabular}


Table 5. Cont.

\begin{tabular}{|c|c|c|c|c|c|c|}
\hline \multirow{2}{*}{ Effect } & \multicolumn{2}{|c|}{ Direct Effect } & \multicolumn{2}{|c|}{ Indirect Effect } & \multicolumn{2}{|c|}{ Total Effect } \\
\hline & Immigrant & Nonimmigrant & Immigrant & Nonimmigrant & Immigrant & Nonimmigrant \\
\hline $\begin{array}{l}\text { Parent Education } \rightarrow \\
\text { Generic ICT Use }\end{array}$ & $0.081 *$ & $0.134^{* *}$ & & & $0.081 *$ & $0.134^{* *}$ \\
\hline $\begin{array}{c}\text { Parent Education } \rightarrow \\
\text { Specific ICT Use }\end{array}$ & $0.406^{* *}$ & $0.307^{* *}$ & & & $0.406^{* *}$ & $0.307^{* *}$ \\
\hline $\begin{array}{c}\text { Home Resources } \rightarrow \text { ICT } \\
\text { Access }\end{array}$ & $0.160^{* *}$ & $0.114^{* *}$ & & & $0.160^{* *}$ & $0.114^{* *}$ \\
\hline $\begin{array}{c}\text { Home Resources } \rightarrow \\
\quad \text { Self-Efficacy }\end{array}$ & 0.005 & 0.202 & $0.122 *$ & -0.119 & $0.127^{* *}$ & $0.084^{* *}$ \\
\hline
\end{tabular}

* Denotes a significance level at $0.05,{ }^{* *}$ denotes a significance level at 0.01 .

Generic ICT use had negative insignificant direct and total effects on math $\left(\beta_{\text {direct }}=-9.758\right.$, $\left.p>0.05 ; \beta_{\text {total }}=-6.56, p>0.05\right)$, but a significant positive total effect on self-efficacy $\left(\beta_{\text {total }}=0.06\right.$, $p<0.01)$. In contrast with insignificant negative effect of generic ICT use, specific ICT use had significant positive direct, indirect, and total effects on math $\left(\beta_{\text {direct }}=5.158, p<0.05 ; \beta_{\text {indirect }}=2.753\right.$, $\left.p<0.05 ; \beta_{\text {total }}=7.910, p<0.01\right)$, and significant positive direct and total effects on math self-efficacy $\left(\beta_{\text {direct/total }}=0.050, p<0.05\right)$. Thus, among immigrant students, a higher frequency of specific ICT use was associated with a higher level of math achievement, differing from no significant association between generic ICT use and math achievement.

In addition to ICT variables, the structural models included gender, parents' education, and home education resources. Overall, the gender variable had significant negative direct and total effects on self-efficacy $\left(\beta_{\text {direct }}=-0.169, p<0.05 ; \beta_{\text {total }}=-0.141, p<0.01\right)$, but significant positive direct and total effects on ICT use for specific purposes $\left(\beta_{\text {direct/total }}=0.571, p<0.01\right)$. Thus, female immigrant students displayed lower self-efficacy, but a higher frequency of specific ICT use, compared with their male counterparts.

Parents' education had a significant effect on math as well as on the ICT variables. Immigrant students whose parents had a higher educational level tended to demonstrate higher math achievement $\left(\beta_{\text {direct }}=6.902, p<0.01\right)$, lower ICT access $\left(\beta_{\text {direct/total }}=-0.108, p<0.05\right)$, more frequent generic ICT use $\left(\beta_{\text {direct } / \text { total }}=0.081, p<0.05\right)$, and more frequent specific ICT use $\left(\beta_{\text {direct } t \text { total }}=0.406, p<0.01\right)$. Similarly, home education resources had significant positive effects on both ICT access and self-efficacy. On average, immigrant students with more home resources had higher ICT access $\left(\beta_{\text {direct/total }}=0.160\right.$, $p<0.01)$ and higher self-efficacy $\left(\beta_{\text {indirect }}=0.122, p<0.05 ; \beta_{\text {total }}=0.127, p<0.01\right)$.

\subsection{Full SEM Model for Nonimmigrant Students (Non-Immigrant Model)}

As shown in Table 4, the non-immigrant model also revealed acceptable fit statistics: $X^{2}=1276.541$, $p<0.05 ;$ RMSEA $=0.045 ; \mathrm{CFI}=0.946 ; \mathrm{TLI}=0.915 ;$ and $\mathrm{SRMR}=0.041$.

Figure 4 reveals the factor loadings and direct effects in the non-immigrant model. The measurement model showed factor loadings for the latent factor of generic ICT use similar to those in the immigrant model. With the factor loading of ICT Generic1 fixed to 1 , the factor loadings of the other two ICT Generic variables, ICT Generic $2(\lambda=0.437, p<0.01)$ and ICT Generic $3(\lambda=1.073$, $p<0.01)$, were significant. For the latent factor variable of specific ICT use, the factor loading of ICT Specific $3(\lambda=1.650, p<0.01)$ was more prominent than the loadings for both ICT Specific $1(\lambda=1)$ and ICT Specific $2(\lambda=1.080, p<0.01)$. With the factor loading of Eff1 set to 1, three Efficacy variables, Eff2 $(\lambda=1.204, p<0.01)$, Eff3 $(\lambda=1.188, p<0.01)$, and Eff4 $(\lambda=0.942, p<0.01)$, were significant. 


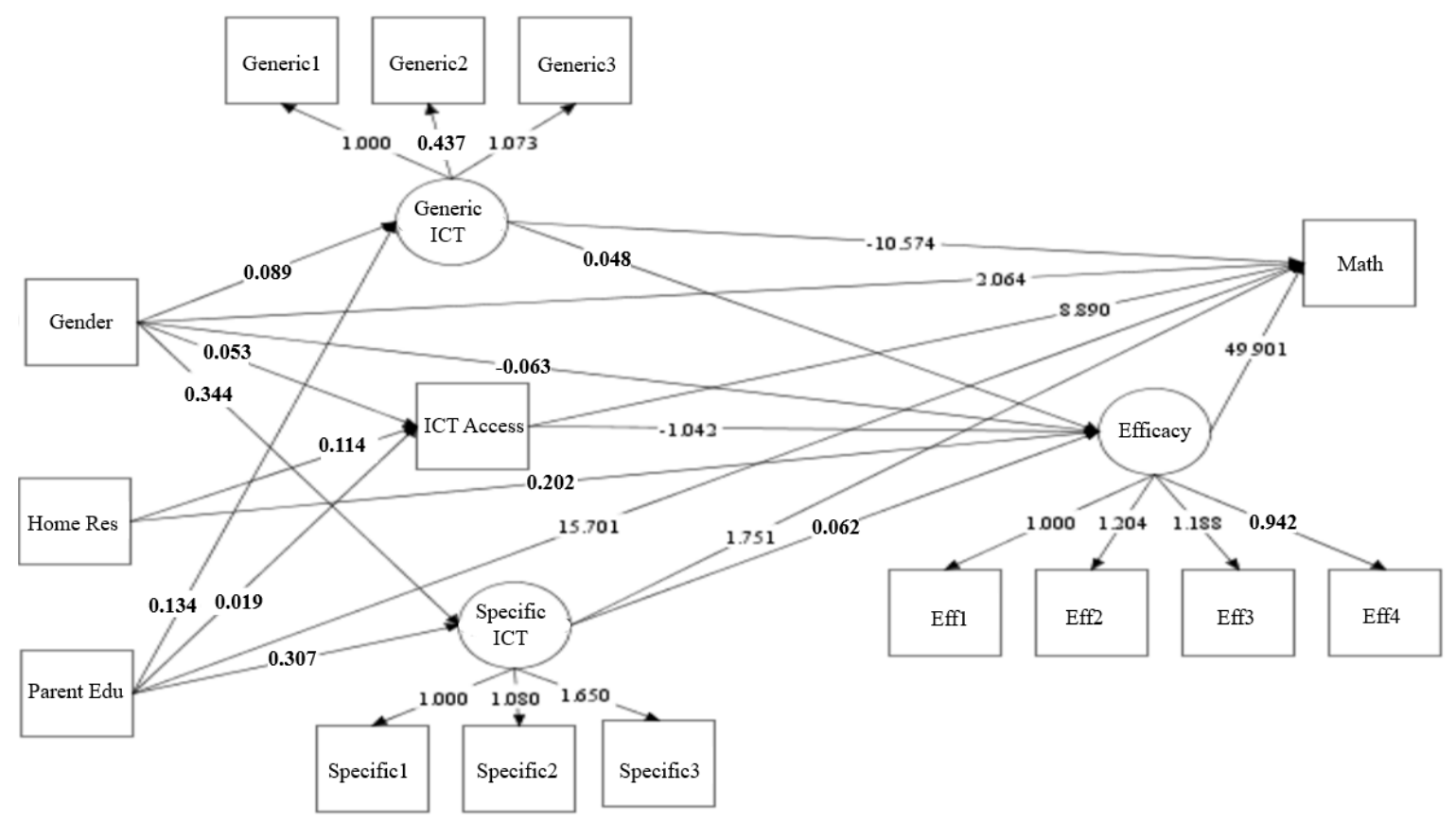

Figure 4. Full SEM Results for Non-immigrant Model.

As shown in the results for the ICT variables in the non-immigrant model (see Figure 4 and Table 5 for details), ICT access had significant positive direct effect on math $\left(\beta_{\text {direct }}=8.890, p<0.01\right)$, but no significant effect on self-efficacy. Generic ICT use had a significant negative direct effect on math $\left(\beta_{\text {direct }}=-10.574, p<0.01\right)$, but a significant positive indirect effect on math $\left(\beta_{\text {indirect }}=2.400, p<0.01\right)$ through self-efficacy, but, in total, it has a significant negative effect on math $\left(\beta_{\text {total }}=-8.174, p<0.01\right)$. On the other hand, specific ICT use had no significant direct effect on math, but significant positive effect on math through self-efficacy $\left(\beta_{\text {indirect }}=3.101, p<0.01 ; \beta_{\text {total }}=4.852, p<0.01\right)$ and significant direct $/$ total effect on self-efficacy $\left(\beta_{\text {direct/total }}=0.062, p<0.01\right)$.

Notably, differing from non-significant effect of generic ICT use among immigrant students, non-immigrant students with higher frequency of generic ICT use tended to show lower mathematics performance. Differing from more pronounced effect of specific ICT use on math among immigrant students including significant direct effect with greater magnitudes of total effect, there was no significant direct effect of specific ICT Use on math, and significant total effect on math can be caused mainly by its significant association with self-efficacy.

The results for gender among non-immigrant students were similar in the case of self-efficacy and specific ICT use. Similar to immigrant students, non-immigrant female students demonstrated lower self-efficacy $\left(\beta_{\text {total }}=-0.093, p<0.01\right)$ but, higher frequency of specific ICT use $\left(\beta_{\text {direct/total }}=\right.$ $0.089, p<0.01)$. However, differing from no-significant gender differences among immigrant students, non-immigrant female students tended to have higher access to ICT $\left(\beta_{\text {direct/total }}=0.053, p<0.05\right)$ and higher frequency of generic ICT use $\left(\beta_{\text {direct } / \text { total }}=0.089, p<0.01\right)$ than non-immigrant male students.

The results on parents' education and home resources among non-immigrant students were similar to the parallel results for immigrant students with the exception of the effect of parents' education on ICT access. Non-immigrant students whose parents had higher educational levels had higher math achievement $\left(\beta_{\text {direct }}=15.701, p<0.01 ; \beta_{\text {total }}=15.258, p<0.01\right)$, and more frequent use of both generic ICT $\left(\beta_{\text {direct/total }}=0.134, p<0.01\right)$ and specific ICT $\left(\beta_{\text {direct/total }}=0.307, p<0.01\right)$. Finally, non-immigrant students with more home education resources had more ICT access $\left(\beta_{\text {direct/total }}=0.114\right.$, $p<0.01)$ and self-efficacy $\left(\beta_{\text {total }}=0.084, p<0.01\right)$. 


\section{Discussion}

The current study contributes to the Sustainable Development Goal of making quality education accessible to all [1], specifically in the context of international migration as a significant global force [88]. The study explored the potential of ICT as a way to provide meaningful learning experiences for immigrant students in the United States, which hosts more international immigrants than any other country and has experienced a $47 \%$ increase in its immigrant workforce in the past 10 years $[1,89]$. The short-term goal of the research is to promote mathematics performance among immigrant students via ICT access and use, and the long-term goal of the research is to facilitate the integration of these immigrant students into their destination country by providing quality education in a way that will make international immigration beneficial for both immigrants and the native population in destination countries.

Using nationally representative data, the study explored the potential of ICT as a meaningful educational intervention for immigrant students. First, this study provides empirical evidence on immigrant risks [6], particularly among first and second-generation immigrant students coming from homes where English is not the dominant language. At home, these immigrant students suffered from immigrant risk factors, including fewer home resources and lower parental educational attainment, compared with their nonimmigrant peers. At school, these immigrant students revealed lower mathematics performance in the TIMSS international assessment, which aligns with national assessment results [9]. Coming from less-English speaking homes might put immigrant students at a disadvantage for acquiring academic English in school [75], thus resulting in poorer achievement in reading/English [90] as well as in mathematics; note that mathematics also requires some linguistic capability if students are to do well (e.g., solve word problems) [91].

The results reveal that ICT access has significant positive direct and total effects on immigrants' math performance and this effect is more pronounced for immigrant students than for non-immigrant students. Unfortunately, despite the disproportionate benefits of ICT access for immigrant students our findings add further empirical evidence for the ICT access divide between immigrant and nonimmigrant students. These results therefore provide empirical support for international and national initiatives to promote ICT access for all [5,10], especially immigrant youths who tend to have less access to ICT than their non-immigrant peers [31]. Despite some doubts about the value of investment in ICT for general student populations [92], these results provide support for continued investment in equalizing ICT access, particularly for schools with a higher proportion of immigrant students who have fewer resources such as ICT at home and in their communities than their nonimmigrant peers $[93,94]$. Furthermore, in order to prioritize investment in ICT, future studies need to explore the separate effects of the various ICT devices (e.g., computers, tablets, and e-readers) included in the present study, whose combined effect was found to be positive.

In addition to examining ICT access, the study investigated the effects of ICT use for educational purposes. The results showed that specific ICT use had significant positive direct, indirect, and total effects for immigrant students, but for nonimmigrant students, its effect was significant only via self-efficacy. These findings provide empirical evidence that can guide decisions about ICT uses for immigrant students in the face of mixed results on the effects of ICT use in prior studies. Specifically, these results underscore the importance of guiding students to use ICT for specific purposes such as connecting ICT use to the curriculum, for example by encouraging students to complete class assignments using ICT. The analytical results supporting specific ICT use in the completion of assignments aligns with the findings of previous studies [48,50]. The results also showed that using ICT for specific purposes such as collaboration and communication had positive effects, possibly because using ICT for collaboration and communication supports a range of constructive practices and skills, particularly problem-solving strategies $[53,55]$. To solve mathematical tasks successfully, students need to adopt appropriate problem-solving strategies to help them comprehend unfamiliar problems; they also need to be persistent, continuing to engage with the problem-solving process even when solutions do not immediately emerge e.g., [38,95]. Thus, students who often utilize ICT for communication 
and collaboration can benefit from the problem-solving strategies they master when working with ICT, and these strategies are likely to improve their mathematics achievement. In contrast with the significant positive effect of specific ICT use, although the effect of generic ICT use was negative for immigrant students, this was not significant. For nonimmigrant students, however, generic ICT use had significantly negative direct/total effects on math achievement despite its significant positive indirect effect through self-efficacy. While generic ICT uses did not cause as much harm for immigrant students as for nonimmigrant students, the negative effects of generic ICT use were identified in prior studies of general student populations [11,12].

By incorporating the study's findings on two different types of ICT uses, future studies could explore the potential of developing personal learning Environments (PLEs) for immigrant students. The study's findings on specific ICT uses for school assignments, communication with teachers, and collaborations with peers show the potential of PLEs as effective pedagogical approaches for immigrant students, emphasizing the incorporation of formal learning into the learning process and connections to other learners and teachers $[96,97]$. Future studies need to address how to motivate and empower immigrant students to build effective and sustainable PLEs for their own learning goals that integrate formal and informal learning (e.g., the adoption of social media to extend school learning in informal settings) and promote participation in collective knowledge construction (e.g., the development/maintenance of informal learning communities where immigrant students receive feedback from their peers and teachers) [98].

In the context of these findings, this study recommends that policymakers and administrators provide professional development opportunities for teachers to learn how to promote meaningful ICT use for specific purposes among immigrant students. While teachers are aware of ICT's potential to facilitate teaching in interesting and varied ways, they have a low level of self-efficacy with regard to effectively incorporating ICT into their teaching practices and insufficient ICT competency to use ICT to promote meaningful learning [99]. Given these limitations, an important first step is to promote teachers' self-efficacy in ICT uses [100]. In addition, policymakers and education administrators should implement a long-term plan to develop teachers' ICT competency over time [101]. One possibility administrators and policymakers should consider is focusing on the development of technical pedagogical content knowledge, which has been found to have a positive influence on both teachers' adoption of ICT during class and students' academic achievement [102].

Considering the significant positive effects of ICT access and specific ICT uses for immigrant students, and in contrast with the less pronounced effect on their nonimmigrant peers, the results of this study support ICT access and ICT uses for specific purposes such as assignment completion, collaboration, and communication as a way to narrow the achievement gap between immigrant and nonimmigrant students, thus advancing successful integration into mainstream populations. Also, based on the current results showing that ICT access and ICT use for specific educational purposes has immediate positive effects on immigrant students' academic achievement, future research should include longitudinal studies examining the effects of ICT access and use for specific purposes on immigrant students' participation in the workforce, especially in STEM fields, and more generally, its effects on the fiscal impact of international migrants on destination countries.

Although there have been some concerns expressed over the potentially negative effect of international migration on the destination countries, recent research has instead revealed the benefits of immigration. For example, in the United States, highly educated immigrants make a net positive fiscal contribution, paying more in taxes than they receive in public benefits [103]. Immigration has also been shown to have a positive effect on both economic development and innovation, with almost no negative effect on native-born residents' employment or average salary in the long term [104]. In view of the potential benefits of immigration, the findings of the current study support the UN's sustainable development goal for education in the US by providing empirical evidence to demonstrate the potential of ICT as a useful tool for educators seeking to provide a quality education for all, focusing on immigrants. Because immigrants are more likely than their non-immigrant counterparts 
to take risks, which can lead to innovation and entrepreneurship, this population of young immigrant students has the potential to contribute innovative solutions in fields such as science and technology that will improve living conditions and national income in their host countries, while simultaneously mitigating the burden on the pension systems of affluent destination countries with rapidly aging populations [105]. The findings of the current study will thus hopefully inspire future studies that will help us identify ICT interventions that could ameliorate the risks that immigrant students face and capitalize on their unique characteristics and contributions.

Funding: This research received no external funding.

Conflicts of Interest: The author declares no conflict of interest.

\section{References}

1. United Nations, Department of Economic and Social Affairs, Population Division. International Migration Report 2017: Highlights; (ST/ESA/SER.A/404); United Nations, Department of Economic and Social Affairs: New York, NY, USA, 2017.

2. Duncan, H.; Popp, I. World Migration Report 2018; International Organization for Migration: Le Grand-Saconnex, Switzerland, 2018.

3. OECD. International Migration Outlook 2018; OECD Publishing: Paris, France, 2018; Available online: https: / / doi.org/10.1787/migr_outlook-2018-en (accessed on 5 November 2018).

4. United Nations, General Assembly. Transforming Our World: The 2030 Agenda for Sustainable Development; A/RES/70/1; United Nations, General Assembly: New York, NY, USA, 2015.

5. OECD. OECD Digital Economy Outlook 2017; OECD Publishing: Paris, France, 2017.

6. Crosnoe, R.; Fuligni, A.J. Children from immigrant families: Introduction to the special section. Child Dev. 2012, 83, 1471-1476. [CrossRef] [PubMed]

7. McFarland, J.; Hussar, B.; Wang, X.; Zhang, J.; Wang, K.; Rathbun, A.; Barmer, A.; Forrest Cataldi, E.; Bullock Mann, F. The Condition of Education 2018 (NCES 2018-144); U.S. Department of Education, National Center for Education Statistics: Washington, DC, USA, 2018. Available online: https://nces.ed.gov/ pubsearch/pubsinfo.asp?pubid=2018144 (accessed on 22 September 2018).

8. Common Core State Standards Initiative. Common Core State Standards for Mathematics; National Governors Association Center for Best Practices and the Council of Chief State School Officers: Washington, DC, USA, 2010.

9. Greiff, S.; Wüstenberg, S.; Csapó, B.; Demetriou, A.; Hautamäki, J.; Graesser, A.C.; Martin, R. Domain-general problem solving skills and education in the 21st century. Educ. Res. Rev. 2014, 13, 74-83. [CrossRef]

10. International Society for Technology in Education. Support for the Digital Learning Equity Act of 2015. Available online: http:/ / staging.iste.org/docs/advocacy-resources/digital-learning-equity-act-of-2015letter-of-support.pdf?sfvrsn=2 (accessed on 4 April 2018).

11. Jonassen, D.H. Revisiting activity theory as a framework for designing student-centered learning environments. In Theoretical Foundations of Learning Environments; Jonassen, D.H., Land, S.M., Eds.; Lawrence Erlbaum Associates: Mahwah, NJ, USA, 2000; pp. 89-121.

12. Weiss, I.; Banilower, E.; McMahon, K.; Smith, P. Report of the 2000 National Survey of Science and Mathematics Education; Horizon Research, Inc.: Chapel Hill, NC, USA, 2001.

13. Yailagh, M.S.; Lloyd, J.; Walsh, J. The causal relationships between attribution styles, mathematics self-efficacy beliefs, gender differences, goal setting, and math achievement of school children. J. Educ. Psychol. 2008, 3, 95-114.

14. Kim, S. ICT for Children of Immigrants: Indirect and Total Effects via Self-Efficacy on Math Performance. J. Educ. Comput. Res. 2018, 55, 1168-1200. [CrossRef]

15. TIMSS 2015. International Association for the Evaluation of Educational Achievement (IEA); TIMSS \& PIRLS International Study Center, Lynch School of Education, Boston College: Chestnut Hill, MA, USA, 2015; Available online: https://timssandpirls.bc.edu/timss2015/international-database/ (accessed on 15 August 2018).

16. Kline, R.B. Principles and Practice of Structural Equation Modeling, 3rd ed.; Guilford Press: New York, NY, USA, 2011. 
17. Balett, C.P. Predicting adolescent's cyberbullying behavior: A longitudinal risk analysis. J. Adolesc. 2015, 41, 86-95. [CrossRef] [PubMed]

18. Mitchell, K.J.; Wells, M.; Priebe, G.; Ybarra, M.L. Exposure to websites that encourage self-harm and suicide: Prevalence rates and association with actual thoughts of self-harm and thoughts of suicide in the United States. J. Adolesc. 2014, 37, 1335-1344. [CrossRef] [PubMed]

19. Mu, K.J.; Moore, S.E.; LeWinn, K.Z. Internet use and adolescent binge drinking: Findings from the monitoring the future study. Addict. Behav. Rep. 2015, 2, 61-66. [CrossRef] [PubMed]

20. Polos, P.G.; Bhat, S.; Gupta, D.; O’Malley, R.J.; DeBari, V.A.; Upadhyay, H.; Chaudhry, S.; Nimma, A.; Pinto-Zipp, G.; Chokroverty, S. The impact of sleep time-related information and communication technology (STRICT) on sleep patterns and daytime functioning in American adolescents. J. Adolesc. 2015, 44, 232-244. [CrossRef] [PubMed]

21. Rideout, V. The Common Sense Census: Media Use by Tweens and Teens; Common Sense Media: San Francisco, CA, USA, 2015.

22. Tapscott, D. Growing up Digital: The Rise of the Net Generation; McGraw-Hill: New York, NY, USA, 1998; Volume 352.

23. Prensky, M. Digital natives, digital immigrants part 1. Horizon 2001, 9, 1-6. [CrossRef]

24. Brown, J.S. Growing up: Digital: How the web changes work, education, and the ways people learn. Change 2000, 32, 11-20. [CrossRef]

25. McHugh, J. Synching up With the iKid: Educators Must Work to Understand and Motivate a New Kind of Digital Learner; Edutopia: Marin County, CA, USA, Octorber 2005; pp. 32-35.

26. Hanman, N. Growing up with the wired generation. Guardian 2005, 10, 2005-2010.

27. Van Laar, E.; van Deursen, A.J.; van Dijk, J.A.; de Haan, J. The relation between 21st-century skills and digital skills: A systematic literature review. Comput. Hum. Behav. 2017, 72, 577-588. [CrossRef]

28. Shank, D.B.; Cotten, S.R. Does technology empower urban youth? The relationship of technology use to self-efficacy. Comput. Educ. 2014, 70, 184-193. [CrossRef]

29. McFarland, J.; Hussar, B.; de Brey, C.; Snyder, T.; Wang, X.; Wilkinson-Flicker, S.; Gebrekristos, S.; Zhang, J.; Rathbun, A.; Barmer, A.; et al. The Condition of Education 2017; (NCES 2017-144); U.S. Department of Education. National Center for Education Statistics: Washington, DC, USA, 2017. Available online: https: / / nces.ed.gov / pubsearch/pubsinfo.asp?pubid=2017144 (accessed on 18 January 2018).

30. Snyder, T.D.; de Brey, C.; Dillow, S.A. Digest of Education Statistics 2015, 51st ed.; (NCES 2016-014); National Center for Education Statistics, Institute of Education Sciences, U.S. Department of Education: Washington, DC, USA, 2016.

31. Kim, S.; Chang, M.; Choi, N.; Park, J.; Kim, H. The Direct and Indirect Effects of Computer Uses on Student Success in Math. Int. J. Cyber Behav. Psychol. Learn. 2016, 6, 48-64. [CrossRef]

32. De Witte, K.; Rogge, N. Does ICT matter for effectiveness and efficiency in mathematics education? Comput. Educ. 2014, 75, 173-184. [CrossRef]

33. Attewell, P.; Battle, J. Home computers and school performance. Inf. Soc. 1999, 15, 1-10. [CrossRef]

34. OECD. PISA 2015 Results (Volume I): Excellence and Equity in Education; OECD Publishing: Paris, France, 2016.

35. Erdogdu, F.; Erdogdu, E. The impact of access to ICT, student background and school/home environment on academic success of students in Turkey: An international comparative analysis. Comput. Educ. 2015, 82, 26-49. [CrossRef]

36. Lowe, G.S.; Krahn, H.; Sosteric, M. Influence of socioeconomic status and gender on high school seniors' use of computers at home and at school. Alberta J. Educ. Res. 2003, 49, 138-154.

37. OECD. OECD Digital Economy Outlook 2015; OECD Publishing: Paris, France, 2015.

38. Wittwer, J.; Senkbeil, M. Is students' computer use at home related to their mathematical performance at school? Comput. Educ. 2008, 50, 1558-1571. [CrossRef]

39. Fariña, P.; San Martín, E.; Preiss, D.D.; Claro, M.; Jara, I. Measuring the relation between computer use and reading literacy in the presence of endogeneity. Comput. Educ. 2015, 80, 176-186. [CrossRef]

40. Nævdal, F. Home-PC usage and achievement in English. Comput. Educ. 2007, 49, 1112-1121. [CrossRef]

41. Papanastasiou, E.C.; Zembylas, M.; Vrasidas, C. Can computer use hurt science achievement? The USA results from PISA. J. Sci. Educ. Technol. 2003, 12, 325-332. [CrossRef]

42. Ponzo, M. Does the way in which students use computers affect their school performance? J. Econ. Soc. Res. 2011, 13, 1-27. 
43. Heemskerk, I.; Brink, A.; Volman, M.; Ten Dam, G. Inclusiveness and ICT in education: A focus on gender, ethnicity and social class. J. Comput. Assist. Learn. 2005, 21, 1-16. [CrossRef]

44. UNESCO. Information and Communication Technologies in Teacher Education: A Planning Guide; UNESCO: London, UK, 2002.

45. Kim, S.; Chang, M. Does Computer Use Promote the Mathematical Proficiency of ELL Students? J. Educ. Comput. Res. 2010, 42, 285-305. [CrossRef]

46. Liu, D.; Kirschner, P.A.; Karpinski, A.C. A meta-analysis of the relationship of academic performance and Social Network Site use among adolescents and young adults. Comput. Hum. Behav. 2017, 77, 148-157. [CrossRef]

47. Akbulut, Y.; Kesim, M.; Odabasi, F. Construct validation of ICT indicators measurement scale (ICTIMS). Int. J. Educ. Dev. Using ICT 2007, 3, 60-77.

48. Cap, O.; Black, J. Digital Comics in Human Ecology: Exploring Learning Possibilities Using ICT with Teacher Education Students. Int. J. Learn. 2012, 18, 27-44. [CrossRef]

49. Dawson, V.; Forster, P.; Reid, D. Information Communication Technology (ICT) integration in a science education unit for preservice science teachers; students' perceptions of their ICT skills, knowledge and pedagogy. Int. J. Sci. Math. Educ. 2006, 4, 345-363. [CrossRef]

50. OECD. Policies and practices to help boys and girls fulfill their potential. In The ABC of Gender Equality in Education: Aptitude, Behaviour, Confidence; OECD Publishing: Paris, France, 2015.

51. Jonassen, D.H. Toward a design theory of problem solving. Educ. Technol. Res. Dev. 2000, 48, 63-85. [CrossRef]

52. Hara, N.; Bonk, C.J.; Angeli, C. Content analysis of online discussion in an applied educational psychology course. Instr. Sci. 2000, 28, 115-152. [CrossRef]

53. Jonassen, D.H. Engaging and supporting problem solving in online learning. Q. Rev. Distance Educ. 2002, $3,1-13$.

54. Jonassen, D.H. Learning to Solve Problems: An Instructional Design Guide; John Wiley \& Sons: Hoboken, NJ, USA, 2004; Volume 6.

55. Jonassen, D.H.; Kwon, H. Communication patterns in computer mediated versus face-to-face group problem solving. Educ. Technol. Res. Dev. 2001, 49, 35. [CrossRef]

56. Bandura, A. Self-Efficacy: The Exercise of Control; Freeman: New York, NY, USA, 1997.

57. Honicke, J. The influence of academic self-efficacy on academic performance: A systematic review. Educ. Res. Rev. 2016, 17, 63-84. [CrossRef]

58. Klassen, R. Writing in early adolescence: A review of the role of self-efficacy beliefs. Educ. Psychol. Rev. 2002, 14, 173-203. [CrossRef]

59. Richardson, M.; Abraham, C.; Bond, R. Psychological correlates of university students' academic performance: A systematic review and meta-analysis. Psychol. Bull. 2012, 138, 353-387. [CrossRef] [PubMed]

60. Isiksal, M. Pre-Service Teachers' Performance in Their University Coursework and Mathematical Self-Efficacy Beliefs: What Is the Role of Gender and Year in Program? Math. Educ. 2005, 15, 8-16.

61. Zhu, Y.-Q.; Chen, L.-Y.; Chern, C.-C. How does Internet information seeking help academic performance? The moderating and mediating roles of academic self-efficacy. Comput. Educ. 2011, 57, 2476-2484. [CrossRef]

62. Chen, L.Y.; Hsiao, B.; Chern, C.C.; Chen, H.G. Affective mechanisms linking Internet use to learning performance in high school students: A moderated mediation study. Comput. Hum. Behav. 2014, 35, 431-443. [CrossRef]

63. Hyde, J.S. The gender similarities hypothesis. Am. Psychol. 2005, 60, 581-592. [CrossRef] [PubMed]

64. Hyde, J.S.; Lindberg, S.M.; Linn, M.C.; Ellis, A.B.; Williams, C.C. Gender similarities characterize math performance. Science 2008, 321, 494-495. [CrossRef] [PubMed]

65. Rutherford, T.; Karamarkovich, S.M.; Lee, D.S. Is the spatial/math connection unique? Associations between mental rotation and elementary mathematics and English achievement. Learn. Individ. Differ. 2018, 62, 180-199. [CrossRef]

66. Zell, E.; Krizan, Z.; Teeter, S.R. Evaluating gender similarities and differences using metasynthesis. Am. Psychol. 2015, 70, 10-20. [CrossRef] [PubMed]

67. Reilly, D.; Neumann, D.L.; Andrews, G. Gender differences in reading and writing achievement: Evidence from the National Assessment of Educational Progress (NAEP). Am. Psychol. 2018. [CrossRef] [PubMed] 
68. Nisbett, R.E.; Aronson, J.; Blair, C.; Dickens, W.; Flynn, J.; Halpern, D.F.; Turkheimer, E. Intelligence: New findings and theoretical developments. Am. Psychol. 2012, 67, 130-159. [CrossRef] [PubMed]

69. Sáinz, M.; Eccles, J. Self-concept of computer and math ability: Gender implications across time and within ICT studies. J. Vocat. Behav. 2012, 80, 486-499. [CrossRef]

70. Annetta, L.; Mangrum, J.; Holmes, S.; Collazo, K.; Cheng, M.-T. Bridging reality to virtual reality: Investigating gender effect and student engagement on learning through video game play in an elementary school classroom. Int. J. Sci. Educ. 2009, 31, 1091-1113. [CrossRef]

71. Vogel, J.J.; Vogel, D.S.; Cannon-Bowers, J.; Bowers, C.A.; Muse, K.; Wright, M. Computer gaming and interactive simulations for learning: A meta-analysis. J. Educ. Comput. Res. 2006, 34, 229-243. [CrossRef]

72. Hatlevik, O.E.; Scherer, R.; Christophersen, K.A. Moving beyond the study of gender differences: An analysis of measurement invariance and differential item functioning of an ICT literacy scale. Comput. Educ. 2017, 113, 280-293. [CrossRef]

73. Homer, B.D.; Hayward, E.O.; Frye, J.; Plass, J.L. Gender and player characteristics in video game play of preadolescents. Comput. Hum. Behav. 2012, 28, 1782-1789. [CrossRef]

74. Willoughby, T. A short-term longitudinal study of Internet and computer game use by adolescent boys and girls: Prevalence, frequency of use, and psychosocial predictors. Dev. Psychol. 2008, 44, 195-204. [CrossRef] [PubMed]

75. Han, W.J. Academic achievement of children in immigrant families. Educ. Res. Rev. 2006, 1, $286-318$.

76. Galindo, C. English Language Learners' Math and Reading Achievement Trajectories in the Elementary Grades: Full Technical Report; National Institute for Early Education Research: New Brunswick, NJ, USA, 2009; Available online: http:/ / nieer.org/publications/nieer-working-papers/english-language-learners-math-and-readingachievement (accessed on 2 March 2018).

77. Kao, G.; Tienda, M. Optimism and achievement: The educational performance of immigrant youth. In The New Immigration: An Interdisciplinary Reader; Psychology Press: London, UK, 2005; pp. 331-343.

78. Muthén, L.; Muthén, B. Mplus User's Guide, 8th ed.; Muthén \& Muthén: Los Angeles, CA, USA, $1998-2017$.

79. Asparouhov, T.; Muthén, B. Exploratory structural equation modeling. Struct. Equ. Model. 2009, 16, $397-438$. [CrossRef]

80. Wang, J.; Wang, X. Structural Equation Modeling: Applications Using Mplus; John Wiley \& Sons: Hoboken, NJ, USA, 2012.

81. Meyers, L.S.; Gamst, G.; Guarino, A.J. Applied Multivariate Research: Design and Interpretation; Sage: Thousand Oaks, CA, USA, 2006.

82. Kline, R.B. Principles and Practice of Structural Equation Modeling; Guilford Publications: New York, NY, USA, 2015.

83. Lomax, R.G.; Schumacker, R.E. A Beginner's Guide to Structural Equation Modeling; Routledge Academic: New York, NY, USA, 2012.

84. Loehlin, J.C. Latent Variable Models: An Introduction to Factor, Path, and Structural Analysis; Lawrence Erlbaum: Hillsdale, NJ, USA, 1987.

85. Loehlin, J.C. Latent Variable Models: An Introduction to Factor, Path, and Structural Equation Analysis; Psychology Press: Florence, KY, USA, 2004.

86. Hu, L.T.; Bentler, P.M. Cutoff criteria for fit indexes in covariance structure analysis: Conventional criteria versus new alternatives. Struct. Equ. Model. 1999, 6, 1-55. [CrossRef]

87. Hair, J.F.; Black, W.C.; Babin, B.J.; Anderson, R.E.; Tatham, R.L. Multivariate Data Analysis; Person: London, UK, 2006; Volume 6.

88. Kerr, S.P.; Kerr, W.R. Economic Impacts of Immigration: A Survey; No. w16736; National Bureau of Economic Research: Cambridge, MA, USA, 2011.

89. Dumont, J.C.; Liebig, T. Is Migration Good for the Economy? Migration Policy Debates, International Migration Division, OECD: Paris, France, 2014.

90. Larson, L.J. The Foreign-Born Population in the U.S.: 2003; Government Printing Office: Washington, DC, USA, 2004.

91. Duong, M.T.; Badaly, D.; Liu, F.F.; Schwartz, D.; McCarty, C.A. Generational Differences in Academic Achievement Among Immigrant Youths A Meta-Analytic Review. Rev. Educ. Res. 2016, 86, 3-41. [CrossRef]

92. Oppenheimer, T. The Flickering Mind: The False Promise of Technology in the Classroom, and How Learning Can Be Saved; Random House: New York, NY, USA, 2003; p. 512. 
93. Ono, H.; Zavodny, M. Immigrants, English ability and the digital divide. Soc. Forces 2008, 86, 1455-1479. [CrossRef]

94. Moon, U.J.; Hofferth, S. Change in Computer Access and the Academic Achievement of Immigrant Children; Teachers College Record 2018, 120, n4; Teachers College, Columbia University: New York, NY, USA, 2018.

95. Schoenfeld, A.H. Learning to Think Mathematically: Problem Solving, Metacognition, and Sense Making in Mathematics (Reprint). J. Educ. 2016, 196, 1-38. [CrossRef]

96. Attwell, G. Personal Learning Environments-the future of eLearning? E-Learn. Pap. 2007, 2, 1-8.

97. Martindale, T.; Dowdy, M. Personal learning environments. In Emerging Technologies in Distance Education; Veletsianos, G., Ed.; AU Press: Edmonton, AB, Canada, 2010.

98. Dabbagh, N.; Kitsantas, A. Personal Learning Environments, social media, and self-regulated learning: A natural formula for connecting formal and informal learning. Internet High. Educ. 2012, 15, 3-8. [CrossRef]

99. Nicholas, K.; Fletcher, J. What is happening in the use of ICT mathematics to support young adolescent learners? A New Zealand experience. Educ. Rev. 2017, 69, 474-489. [CrossRef]

100. Hatlevik, O.E. Examining the relationship between teachers' self-efficacy, their digital competence, strategies to evaluate information, and use of ICT at school. Scand. J. Educ. Res. 2017, 61, 555-567. [CrossRef]

101. Hsu, S. Developing and validating a scale for measuring changes in teachers' ICT integration proficiency over time. Comput. Educ. 2017, 111, 18-30. [CrossRef]

102. Koh, J.H.L.; Chai, C.S.; Lim, W.Y. Teacher professional development for TPACK-21CL: Effects on teacher ICT integration and student outcomes. J. Educ. Comput. Res. 2017, 55, 172-196. [CrossRef]

103. Orrenius, P.M. New Findings on the Fiscal Impact of Immigration in the United States; Federal Reserve Bank of Dallas: Dallas, TX, USA, 2017.

104. Rueben, K.S.; Gault, S. State and Local Fiscal Effects of Immigration; Urban Institute: Washington, DC, USA, 2017.

105. McAuliffe, M.; Ruhs, M. Making Sense of Migration in an Increasingly Interconnected World; IOM World Migration Report 2018; IOM: Geneva, Switzerland, 2017.

(C) 2018 by the author. Licensee MDPI, Basel, Switzerland. This article is an open access article distributed under the terms and conditions of the Creative Commons Attribution (CC BY) license (http:/ / creativecommons.org/licenses/by/4.0/). 